\title{
EDITORIAL
}

\section{Tradable rights in conservation: useful policy tool or industry in themselves?}

In recent decades, markets have become widely used for environmental resources. Prime examples include water rights where trade enables water to be allocated to the most profitable crops, and allows farmers more flexibility to cope with climatic variability (Bjornlund 2003). Similarly, tradable rights for air pollution minimize the cost of meeting air quality targets (Stavins 1998). The same principles can potentially be widely applied to biodiversity conservation. In this issue, we are fortunate to have a short but diverse series of papers on tradable rights in conservation.

Ganzhorn et al. (2015) argue that tradable harvest rights might improve the prospects of a critically endangered tortoise in Madagascar. Currently there is market demand but no one owns rights to the animals, resulting in a tragedy of the commons as the population is over-exploited. Ganzhorn et al. suggest that if local communities could own rights to harvest the tortoise, they would have the incentive to manage the population in a sustainable manner, and to do what they could to prevent poaching. While harvesting wildlife is repugnant to many, if well managed it can have positive conservation and livelihood benefits. Of course community-based management is not without its problems (Dressler et al. 2010), but for the many species threatened by unsustainable harvesting the status quo is clearly not working, so alternatives must be considered.

Legitimizing wildlife harvesting is not without risk, as trade may also provide opportunities for poachers. Advances in genetic and digital technologies mean there is ever greater potential for affordable testing, tracking and monitoring to combat poaching. However, without reasonable governance creating tradable rights for conservation is unlikely to be feasible (nor is it likely to be a priority), as corruption undermines sustainable trade (Bennett 2015), and indeed conservation more broadly (Smith et al. 2015). It is therefore not surprising that most implementations of biodiversityrelated trading schemes have been in more developed countries with the necessary governance institutions in place. The vast majority of such schemes involve tradable quotas in fisheries or tradable development offsets.

Santos et al. (2015) describe how tradable development rights fit into the conservation policy mix. These marketbased approaches enable conservation targets to be met in a more flexible manner than a straight regulatory approach would allow. They are essentially a tool to allow development to proceed efficiently within regulatory constraints, rather than a conservation focused instrument. There are inevitable tensions between economic efficiency, maximized by allowing trades across a wide area (whether geographical or ecological), and ecological integrity, which requires like-for-like offsets. Determining offset requirements is seldom straightforward, perhaps because biodiversity is ultimately not divisible, nor fungible, so the commodification required for efficient markets can prove elusive. Miller et al. (2015) provide a rare insight into the process of integrating ecological science into a practical policy programme. The authors, a mix of public servants and university scientists, show how academic research informed the design of an environmental offset policy in Australia. Such collaborations are likely to be challenging on all sides, but are essential for rigorous policy development.

Offsetting development through habitat restoration, while attractive in principle, is questionable in practice, as it is a slow process, and ecological outcomes are uncertain and difficult to measure (Maron et al. 2012). Once a development has taken place, there is likely to be little interest in the long-term effectiveness of ecological offsets as developers and regulators have moved on to other projects. Time lags are a particular issue for habitat restoration in slow-growing temperate forests. Weber et al. (2015) show how temporary offsets can be used to maintain biodiversity while development occurs, but still there are trade-offs between ecological integrity and cost minimization.

Mann and Simons (2015) describe the emergence of conservation offset trading schemes in the USA and internationally. They observe that a community of interested parties has evolved to promote such trading, which can mean that alternatives are not fully considered. Lockhart (2015) provides a political economic account of biodiversity offsetting in England, revealing the contests of ideas encountered as the government attempted to implement a national scheme. Both studies show how offsetting creates opportunities for individuals and organizations, but in doing so it may give rise to an 'offsetting industry' which can take on a life of its own. These papers are also a reminder that scientists themselves are often actors in these processes. While such deep involvement is essential, there is also a need for some to remain on the outside to provide a more independent perspective.

While attractive in theory, in practice tradable rights for conservation appear to have made relatively little headway, particularly compared to their more illustrious counterparts in markets for pollution and water rights. Trade itself does not drive conservation outcomes, but rather minimizes the costs of meeting targets, for example by allowing small quota holders to sell out or by enabling developers to meet their conservation obligations on less valuable real estate. Minimizing costs helps 
secure stakeholder support, and ultimately means more can be achieved within resource constraints. However, the greater the reach and complexity of a trading scheme, the greater the potential for it to be undermined, for example by loopholes admitting poor-quality projects.

There is a danger that tradable rights schemes become an industry in themselves, rather than simply a policy tool (Spash 2010). Many stand to benefit from the granting of offset rights, including developers, assessors and even governments (who are increasingly tempted to claim the upside, though not the downside, of tradable development offsets towards meeting their own environmental commitments; see Maron et al. 2015). Some offsets may represent nothing more than wishful thinking (Quétier et al. 2014), but few stand to gain from pointing this out. Rigorous and independent science is therefore essential, both to inform the design and test the outcomes of such schemes. This will ensure that tradable rights schemes remain good servants, rather than becoming bad masters.

\section{References}

Bennett, E.L. (2015) Legal ivory trade in a corrupt world and its impact on African elephant populations. Conservation Biology 29: 54-60.

Bjornlund, H. (2003) Efficient water market mechanisms to cope with water scarcity. International fournal of Water Resources Development 19: 553-567.

Dressler, W., Büscher, B., Schoon, M., Brockington, D., Hayes, T., Kull, C.A., McCarthy, J. \& Shrestha, K. (2010) From hope to crisis and back again? A critical history of the global CBNRM narrative. Environmental Conservation 37: 5-15.

Ganzhorn, J.U., Manjoazy, T., Päplow, O., Randrianavelona, R., Razafimanahaka, J.H., Ronto, W.M., Vogt, E., Wätzold, F. \& Walker, R.C.J. (2015) Rights to trade for species conservation: exploring the issue of the radiated tortoise in Madagascar. Environmental Conservation 42(4): 00-00.

Lockhart, A. (2015) Developing an offsetting programme: tensions, dilemmas and difficulties in biodiversity market-making in England. Environmental Conservation 42(4): 00-00.
Mann, C. \& Simons, A. (2014) Local emergence and international developments of conservation trading systems: innovation dynamics and related problems. Environmental Conservation 42(4): $00-00$.

Maron, M., Hobbs, R.J., Moilanen, A., Matthews, J.W., Christie, K., Gardner, T.A., Keith, D.A., Lindenmayer, D.B. \& McAlpine, C.A. (2012) Faustian bargains? Restoration realities in the context of biodiversity offset policies. Biological Conservation 155: 141148.

Maron, M., Gordon, A., Mackey, B.G., Possingham, H.P. \& Watson, E.M. (2015) Stop misuse of biodiversity offsets (Comment). Nature 523: 401-403.

Miller, K.L., Trezise, J.A., Kraus, S., Dripps, K., Evans, M.C., Gibbons, P., Possingham, H.P. \& Maron, M. (2015) The development of the Australian environmental offsets policy: from theory to practice. Environmental Conservation 42(4): $00-00$.

Quétier, F., Regnery, B. \& Levrel, H. (2014) No net loss of biodiversity or paper offsets? A critical review of the French no net loss policy. Environmental Science and Policy 38: 120-131.

Santos, R., Schröter-Schlaack, C., Antunes, P., Ring, I. \& Clemente, P. (2015) Reviewing the role of habitat banking and tradable development rights in the conservation policy mix. Environmental Conservation 42(4): 00-00.

Smith, R.J., Biggs, D., St. John, F.A.V., 't Sas-Rolfes, M. \& Barrington, R. (2015) Elephant conservation and corruption beyond the ivory trade. Conservation Biology 29: 953-956.

Spash, C.L. (2010) The Brave New World of carbon trading. Nem Political Economy 15: 169-195.

Stavins, R.N. (1998) What can we learn from the grand policy experiment? Lessons from $\mathrm{SO}_{2}$ allowance trading. The fournal of Economic Perspectives 12: 69-88.

Weber, M., Hauer, G. \& Farr, D. (2015) Economic-ecological evaluation of temporary biodiversity offsets in Alberta's boreal forest. Environmental Conservation 42(4): 00-00.

ANDREW REESON, Guest Editor

CSIRO, GPO Box 664,

Canberra, ACT 2601 Australia

e-mail: andrem.reeson@csiro.au 